\title{
5. 淡路島吹上浜の砂浜面積・汀線の経年変化
}

\author{
宇野 宏司 $^{1 *} \cdot$ 柿谷 茂貴 ${ }^{1} \cdot$ 辻本 剛三 ・ 柿木 哲哉 $^{1} \cdot$ 出口 一郎 ${ }^{2} \cdot$ 有田 守 $^{2}$ \\ 1神戸市立工業高等専門学校都市工学科（† 651-2194 兵庫県神戸市西区学園東町8-3） \\ 2 大阪大学大学院工学研究科 地球総合工学専攻（广565-0871 大阪府吹田市山田丘2-1） \\ * E-mail:uno@kobe-kosen.ac.jp
}

\begin{abstract}
淡路島南西部に位置する吹上浜を対象に，過去36年間の航空写真を用いて，砂浜面積および護岸から汀 線までの距離の経年変化を把握した。.また, 飛砂・漂砂を考える上で重要となる吹上浜周辺の風特性につ いて把握するため, 気象庁の風向風速データを整理し，それを用いた日飛砂量の推算を行った。 その結果, 吹上浜においては過去 36 年間にわたり, 砂浜面積, 護岸からの汀線距離ともに動的に安定した砂浜である と判断された。.また, 現地の平均風速は概ね $3 \mathrm{~m} / \mathrm{s}$ 程度であり, この程度の風では粒径 $0.1 \mathrm{~mm}$ 程度の飛砂し か起こりえない. 一方, 台風接近や冬季風浪により $10 \mathrm{~m} / \mathrm{s}$ 以上の風が出現することもわかった。ささらに, 月別平均風速および出現風向特性を考慮した飛砂量計算では, 春季から夏季にかけて南から北方向, 冬季 は西から東方向への飛砂が卓越することが明らかにされた.
\end{abstract}

Key Words : Fukiagehama beach, blown sand, cluster analysis, shoreline, aerial photograph

\section{1. はじめに}

瀬戸内海国立公園の東部に位置する淡路島は, 大阪 湾・播磨灘・紀伊水道・明石海峡・鳴門海陕といった水 域に挟まれている，周辺の海岸総延長は約 $212 \mathrm{~km}$ で, 松 帆浦や慶野松原などの名勝地が多いことでも知られる.

淡路島は，台風銀座の一角に位置するため，1961（昭 和36）年の第2室戸台風をはじめ, 多くの台風が来襲し, 高潮・浸水・浸食などの被害を受けてきた. また, 冬季 風浪や外洋からのうねりによって, 沿岸域が著しく侵食 されていることも問題となっている.

1999 (平成11）年の海岸法改正受けて, 防護・環 境・利用の調和のとれた海岸を形成するため, 国が海岸 保全の基本方針を定め, 都道府県がそれを踏まえた海岸 保全基本計画を策定することとなった。淡路島において も, 兵庫県が2002（平成14）年8月に「淡路沿岸海岸保 全基本計画」を策定し，「人と自然が創り出す 21 世紀 のくにうみ神話」「生命を守り・育む花と緑あふれる 海辺の創造」をテーマに海岸整備が進められている1).

本研究で対象とする吹上浜（写真-1）は, 淡路島の南 西部に位置し, 東西約 $2 \mathrm{~km}$ に拡がる砂浜で, 北側は丘陵 地もしくは断崖となっており, 南側が紀伊水道に面して いる（図-1）.

この吹上浜は, オオヒョウタンゴミムシ（Scarites sulcatus Olivier）といった絶滅危機にさらされている昆虫
の生息地，ハマゴウ（Vitex rotundifolia L. f.）等の海浜植物 群落地, アカウミガメ (Caretta caretta) の産卵地として 知られている. 近くには青少年向けの研修施設やオート キャンプ場も整備されており, 環境学習やレクリエーシ ヨンの場としても利用されるなど，人と自然の関わりの 観点からみても貴重な空間を提供している.

吹上浜周辺においては，前述の「淡路沿岸海岸保全基 本計画」で潜堤, 突堤, 養浜等の海岸保全整備が計画さ れている. 現時点での吹上浜の土砂動態を把握すること は，これらの保全施設の効果的な整備を検討する上で, 極めて重要である.

砂浜の上うな数百m〜数 $\mathrm{km}$ の領域の環境モニタリング では，航空写真を用いたローカルリモートセンシングが 有効であるとされている．特に，砂浜面積の算出や汀線 の判読には, 数十 $\mathrm{cm}$ 解像度を有する航空写真で十分 可能である.

以上のことから, 本研究では過去36年にわたり吹上浜 上空で撮影された航空写真を対象に，目視及び画像解析 による砂浜面積の算出を行い，吹上浜の土砂動態の経年 変化について検討することを目的とする．また，飛砂・ 漂砂の重要なパラメータとなる風向・風速の出現特性に ついても着目し, 吹上浜の土砂動態との関連性について 考察した. 


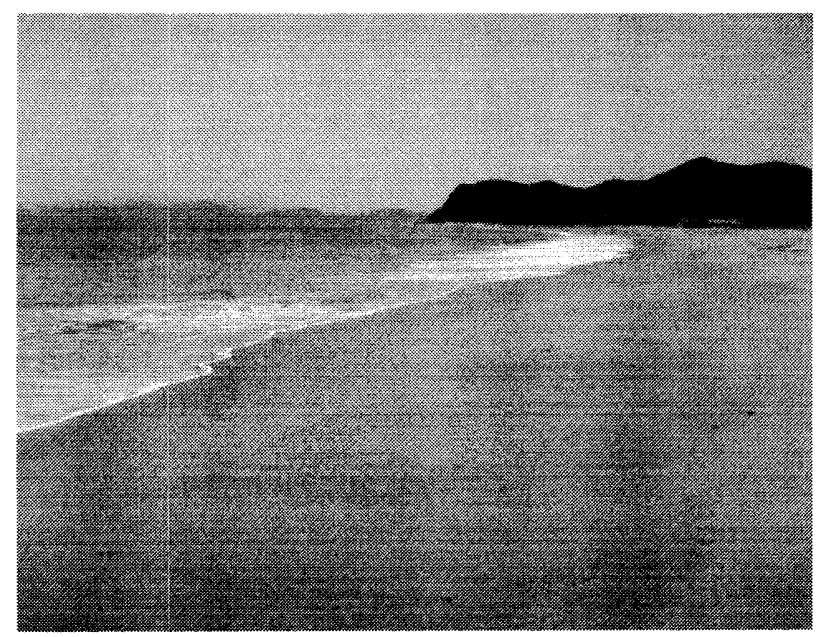

写真-1 吹上浜（2006年8月撮影）

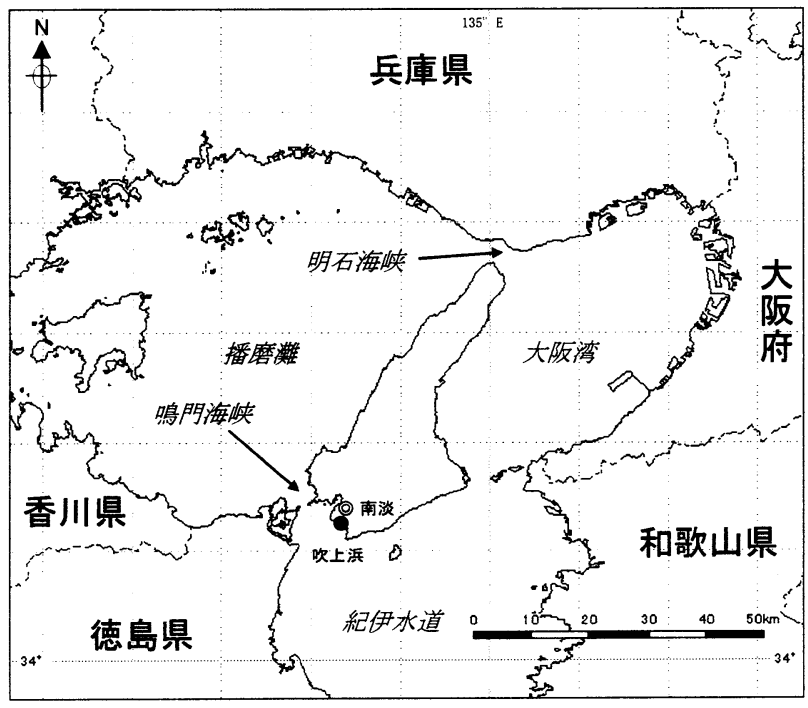

図-1 調查地点

\section{2. 研究方法}

(1) 使用データ

使用した航空写真の一覧を表-1に示す．解析対象期間 は，1968（昭和43）年から2004（平成16）年までの36年 間である. 撮影年によって，モノクロ・カラーの違いが あるため，画像解析による砂浜領域の抽出の際には，力 ラ一画像についてはモノクロ画像に変換後, 解析を行っ た. 本研究では吹上浜の砂浜面積の経年変化の把握を目 的とするため，また単バンドでの分析効果を上げる意味 からも，周辺陸地はできるだけマスキングを行った.

吹上浜東端では塩屋川と本庄川の 2 河川が合流し海に 流入している (図-4参照) が，両河川とも年間を通じて 流量は少なく，これらの河川からの土砂の供給は考えに くい.ここでの砂の移動は，風による飛砂や漂砂に支配 されるものと予想される. 特に, 吹上浜周辺の丘陵地に は風力発電施設が数多く設置されていることから，年間 を通じてある程度の風が吹いているものと思われる，そ 表-1＼cjkstart解析に使用した航空写真

\begin{tabular}{rrrrrl}
\hline No. & 日付 & 撮影時刻 & $\begin{array}{c}\text { 解像度 } \\
(m)\end{array}$ & $\begin{array}{c}\text { T.P. Omとの } \\
\text { 水位差 } \\
(m)\end{array}$ & 備考 \\
\hline \hline 1 & $1968 / 5 / 14$ & $9: 58$ & 0.27 & -0.19 & モノクロ \\
2 & $1970 / 5 / 22$ & $10: 56$ & 0.28 & -0.63 & モノクロ \\
3 & $1975 / 3 / 9$ & $11: 46$ & 0.29 & -0.08 & カラー \\
4 & $1981 / 12 / 26$ & $10: 46$ & 0.28 & -0.03 & モノクロ \\
5 & $1983 / 4 / 25$ & $11: 42$ & 0.33 & -0.46 & カラー \\
6 & $1986 / 5 / 12$ & $14: 53$ & 0.28 & -0.67 & モノクロ \\
7 & $1991 / 5 / 14$ & $14: 51$ & 0.27 & -0.30 & モノクロ \\
8 & $1996 / 10 / 17$ & $13: 03$ & 0.45 & 0.17 & カラー \\
9 & $1999 / 4 / 21$ & $14: 23$ & 0.29 & -0.53 & モノクロ \\
10 & $2000 / 5 / 29$ & $14: 42$ & 0.28 & 0.41 & モノクロ \\
11 & $2003 / 4 / 16$ & $11: 19$ & 0.28 & -0.69 & モノクロ \\
12 & $2004 / 8 / 21$ & $12: 47$ & 0.32 & 0.13 & カラー \\
\hline
\end{tabular}

こで本研究では，気象庁のアメダスデータ（観測地点 「南淡」，北緯34度13.1分，東経134度43.2 分，標高： $5 \mathrm{~m} ）$ の風向・風速データを使用し，季節ごとの平均風 速や風向の出現特性を調べた. また, 淡路島周辺を通 過した台風についても整理を行った。

\section{（2）砂浜面積の算出方法}

画像解析ではフリーソフトウェアMultiSpecを使用した. 画像解析による砂浜面積の算出手順を以下に示す。 ず,解析画像にクラスタ分析を実施し, 輝度值に応じて

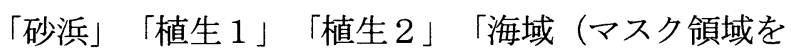
含む）」の 4 領域に分類した. 図-2に分類結果の例を示 す。土地被覆が比較的単調かつ明瞭であるため，単バ ンドの情報でも十分良好な分類結果が得られているこ とがわかる. 次に，「砂浜」に分類された領域の総画 素数と解像度から, 撮影時の砂浜面積を算出する. 画像 によって撮影時刻が異なるため, 別画像の砂浜面積との 比較を行うにはある基準水面での砂浜面積に補正する必 要がある. 本研究では，小松島港（北緯34度01分，東経 134度35分）での実測潮位または推算潮位に小松島から 吹上浜までの位相差を考慮して撮影時の潮位（T.P. 基 準) を求め，基準水面（T.P.Om）との水位差と汀線付近 の地形勾配 $1 / 10$ を用いて補正砂浜面積を算出した. 算出 した補正砂浜面積を撮影時の砂浜面積に加えて各年の砂 浜面積とし，吹上浜における砂浜面積の経年変化を把握 した.

なお，画像解析による砂浜面積算出結果の妥当性を確 認するため, 目視による砂浜面積の概算も行った．概算 方法は, 砂浜東端, 中央部, 砂浜西端のそれぞれにおい て陸側 (護岸) と汀線の位置座標を読み取り，へロン公 式によって簡易的に求めたものである．また，砂浜東端， 中央部，砂浜西端それぞれにおける護岸から汀線までの 距離を読み取り，その経年変化についても把握した。 

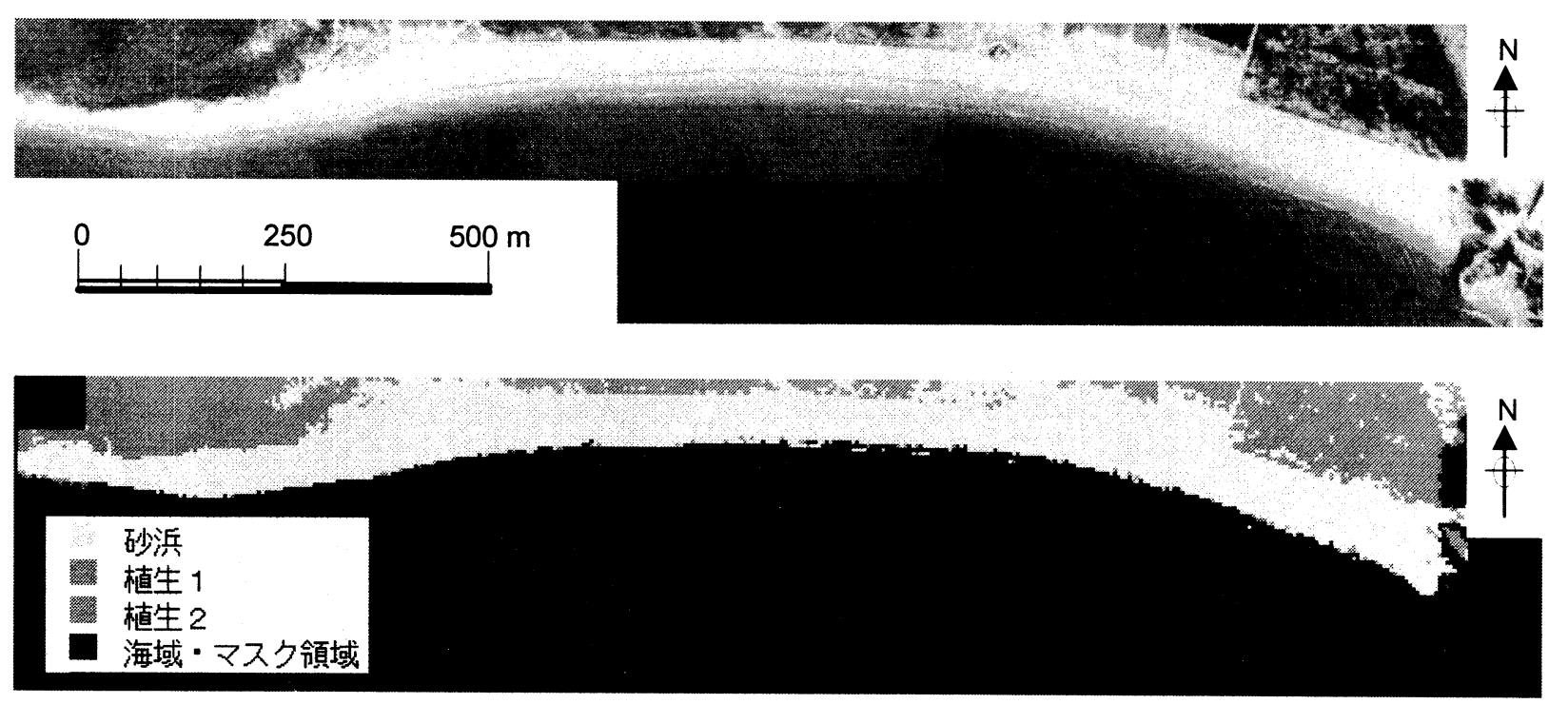

図-2 クラスタ分析結果（上 : オリジナル画像（1968 年），下 : クラスタ分析結果）

1970 年 5 月（汀線 T.P. $-0.63 \mathrm{~m}$ )

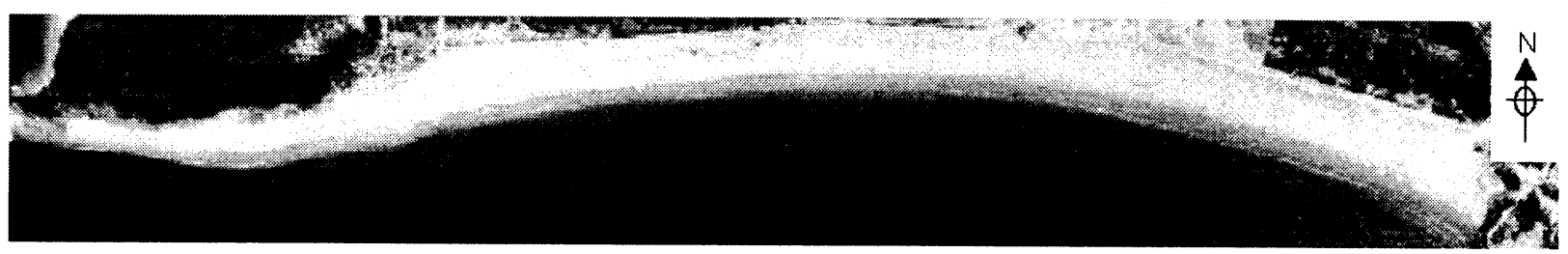

1991 年 5 月（汀線 T.P. $-0.30 \mathrm{~m}$ )

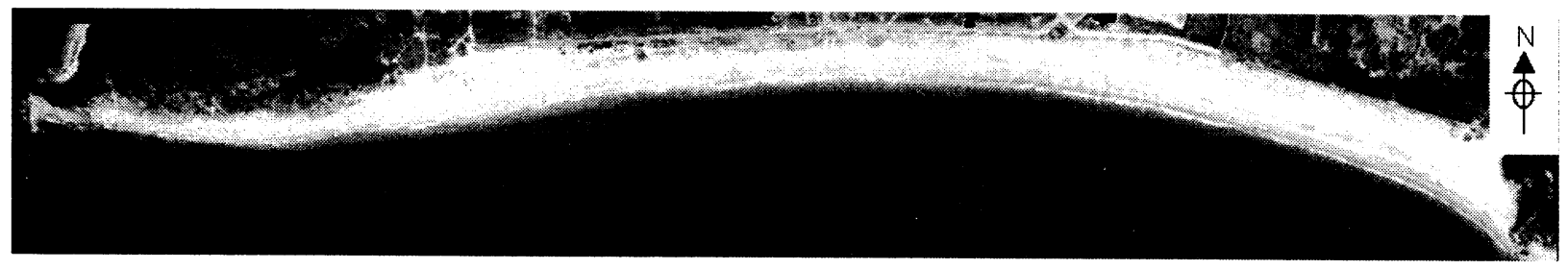

2004 年 8 月（汀線 T.P. +0. 13m）

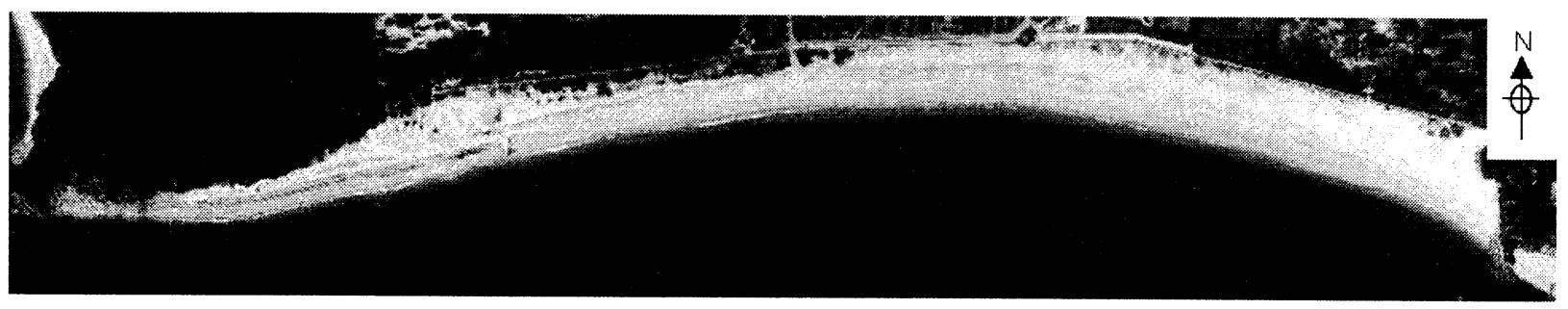

写真-2 吹上浜の様子（上から 1970 年, 1991 年, 2004 年)

\section{（3）気象データの整理方法}

気象庁ホームページの気象統計情報²では，観測点 「南淡」のアメダスデータは1979年以降のデータが公開 されている.ここでは，1979年，1986年，1996年，2006 年の月別風向風速データを整理し，季節ごとの平均風速 及び風向の出現特性について把握した. また, 夏季から 秋季にかけては淡路島周辺は台風の通過点となり，これ により砂浜が大きく変動する可能性も考えられる. そこ で，淡路島に上陸もしくは付近を通過した台風の数につ いても整理した.

\section{（4）日飛砂量の推定方法}

1979～2004年のアメダスデータより算出される各月の 平均風速と風向出現頻度を用いて, 方向別日飛砂量を推 算した.

いま, 砂粒が運動を開始する移動限界摩擦速度 $u_{*_{c}}$ は 次式(1)で評価することができる3).

$$
u_{*_{c}}=A \sqrt{\frac{\rho_{s}-\rho_{a}}{\rho_{a}} g d}
$$




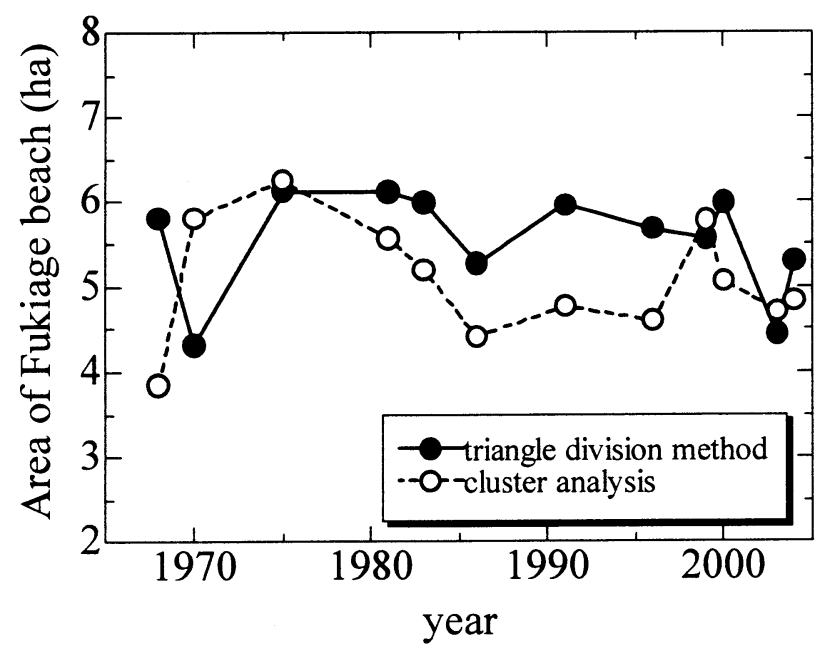

図-3吹上浜における砂浜面積の経年変化

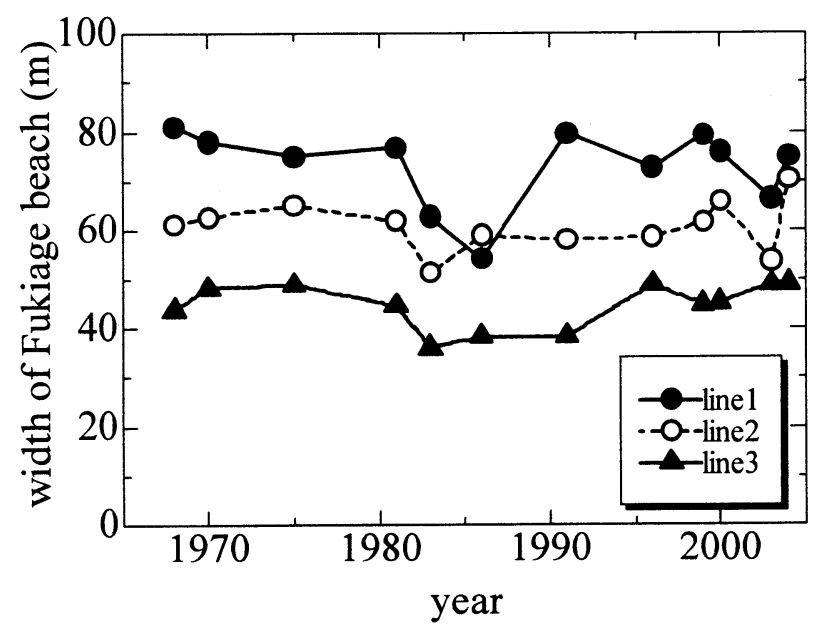

図-5 吹上浜における護岸一汀線間距離の経年変化

ここに, $\rho_{s}$ : 砂粒の密度, $\rho_{a}$ : 空気の密度, $d$ : 砂 粒の粒径, $A$ : 係数 $(=0.1)$ である.

河村は，砂粒間に仔仕する水U表面張力などけ影響を 考慮して，単位幅，単位時間当たりにある断面を通過す る全飛砂量 $Q$ を次式で評価した4).

$$
Q=K \frac{\rho_{a}}{\rho_{s} g}\left(u_{*}-u_{*_{c}}\right)\left(u_{*}+u_{*_{c}}\right)^{2}
$$

ここに $K$ : 係数 $(=2.78), u_{*}$ : 摩擦速度である. 摩 擦速度 $u_{*}$ の評価は, 河田が提案する経験式りを用いた.

\section{3. 解析結果}

\section{(1) 吹上浜の砂浜面積 · 汀線の経年変化}

写真-2は，上空からの吹上浜の様子を1970年，1991年， 2004年の順に示したものである. 撮影時刻が異なるため, 遡上域の干出・水没を考慮する必要があるが, 砂浜面積 に目立つた増减はなく動的に安定しているものと判断で きる. 砂浜中央部についてみると，1970年には確認でき なかった海浜植生群落が1991年の写真では見られ，2004

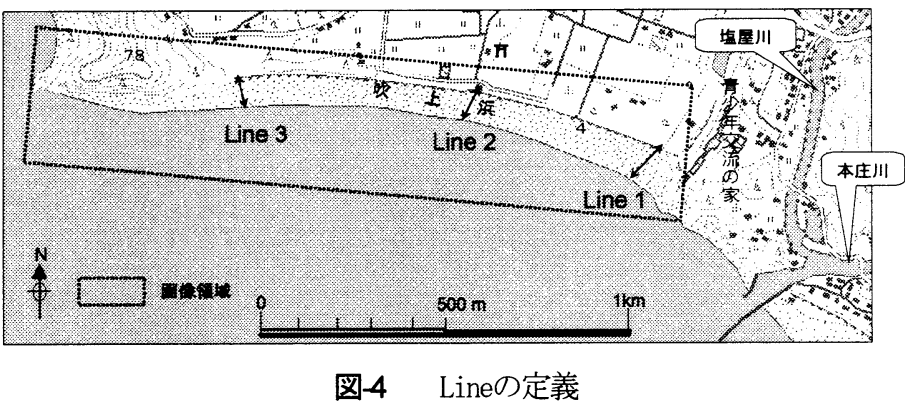

年には護岸に添う形で分布域を東方向に扡大している様 子が見てとれる. 一方, 砂浜西端付近では，1991年に植 生が激しく侵食され，地表がむき出しになっている箇所 が見られるが，2004年にはこの地点の植生が回復してい る様子がわかる。

図-3に吹上浜における砂浜面積の経年変化を示す，目 視により算定された砂浜面積, クラスタ分析により「砂 浜」と判断された領域の面積ともに，1985年，2003年に 大きく減少しているが，過去36年間は変動しながらも 5.5ha前後で動的に平衡状態にある様子がうかがえる. 目 視による面積算定結果がクラスタ分析による分類結果よ りも面積が広くなる傾向が見受けられるが，この理由と しては, クラスタ分析では砂浜内に繁茂する海浜植生群 を「植生」領域に認識するため，その分だけ砂浜面積が 減少するからであると考えられる.

次に，吹上浜のどの領域の地形が変動しやすいのかを 把握するため, 図-4に示す各ラインの長さ（護岸一汀線 間距離）を読み取った。ここでは，各ラインの両端点の 座標位置を読み取り, 座標距離に 1 画素当りの長さを乗 じてライン長を算出した. 図-5に吹上浜における護岸一 汀線間距離の経年変化を示す．吹上浜では，東端の Line 1での護岸一汀線間距離が最も長く $80 \mathrm{~m}$ 程度となっ ている，一方，護岸－汀線間距離が最も短いのは，西端 のLine 3で $40 \mathrm{~m}$ 程度となっている. 各ラインとも変動し ながらも，過去36年間に汀線の顕著な前進や後退は見ら れない. 特に西端のLine 3は最も安定している.1985年 の一時的な砂浜面積の減少は, Line 1 (砂浜東端) での 護岸一汀線間距離の後退，2003年の一時的な砂浜面積の 減少は, Line 1 (砂浜東端) 及ひLine 2（砂浜中央部）で の護岸一汀線間距離の後退によるものである.

\section{（2）吹上浜周辺の風の出現特性}

図-6は，気象庁のアメダス観測地点「南淡」における 1979年, 1986年, 1996年, 2006年の風向データをもとに, 一日の最多出現風向の頻度を整理したものである.ここ では，季節の区分を春季（3月から5月），夏季（6月か ら8月），秋季（9月から11月），冬季（12月から翌年2 月）とし，それぞれひと月あたりの平均日数で表示して 

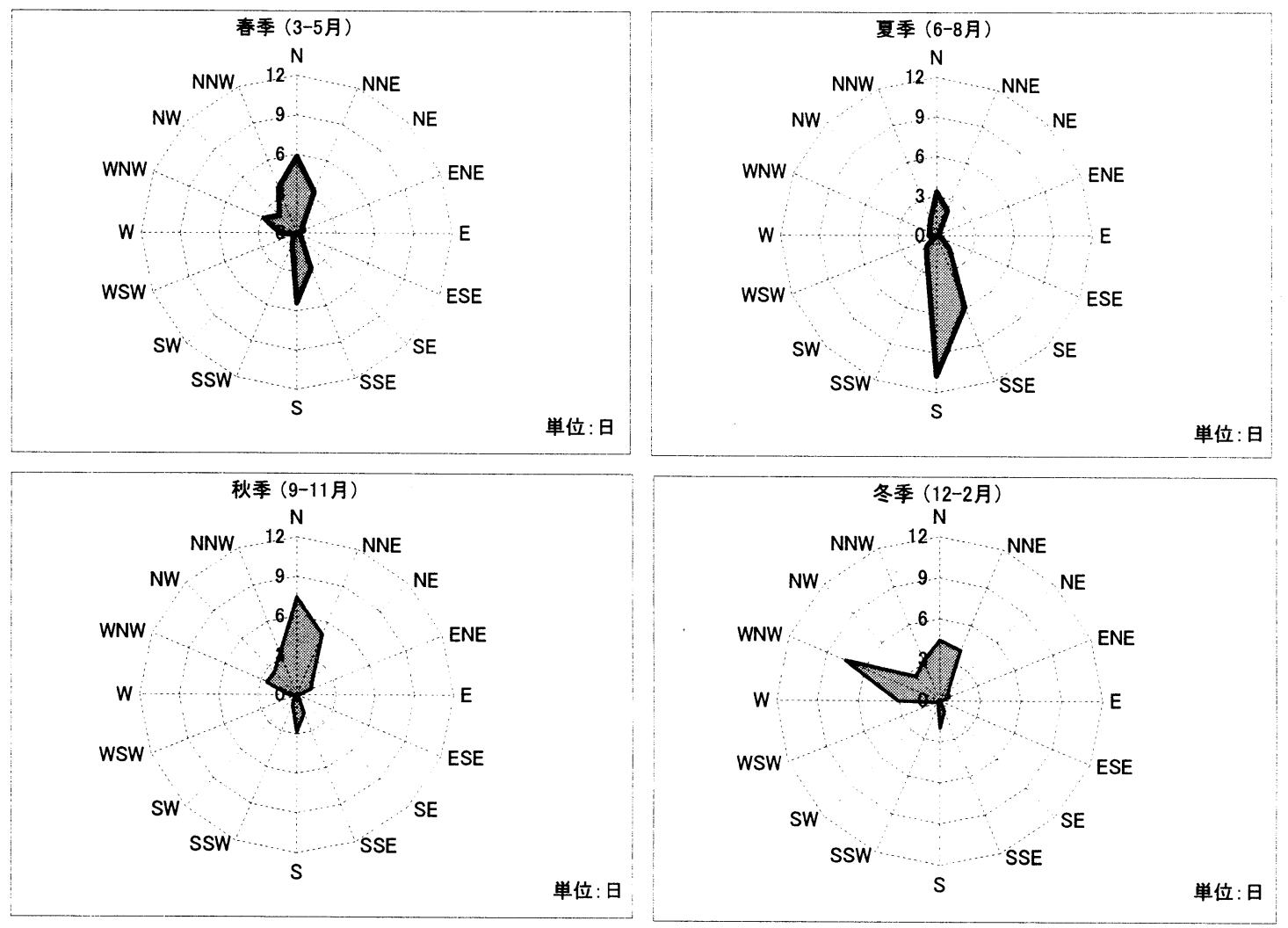

図-6 吹上浜周辺の出現風向頻度（観測点・南淡）

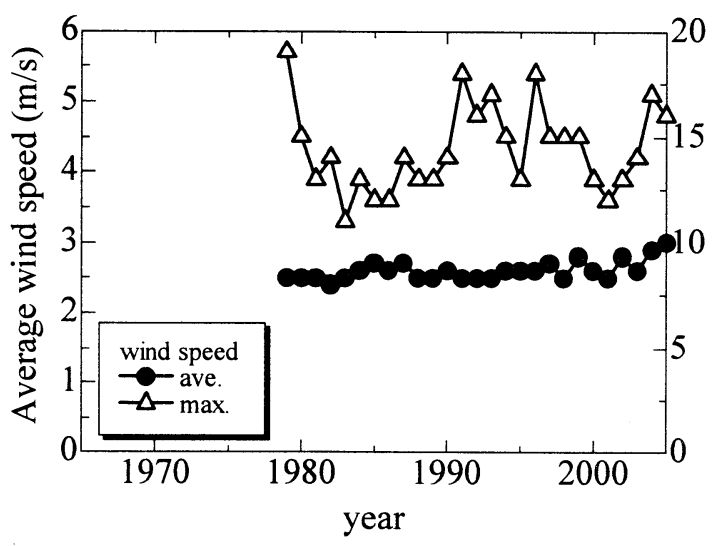

図-7 平均風速と最大風速（観測点 : 南淡）

いる.この図より，夏季を除いては，北から北西方向の 風の出現が卓越していることがわかる．また，夏季につ いては，南寄りの風が卓越している，この時の風速をみ るとそのほとんどが $10 \mathrm{~m} / \mathrm{s}$ 以上となっていた。これは台 風の接近・通過によるものであると考えられる.

図-7は気象庁アメダスの観測地点「南淡」における平 均風速と最大風速の経時変化を示したものである. 平均 風速については，1979年以来，3m/程度でほぼ横ばいと なっている，一方，最大風速については，年によってば らつきが見られるが，図-8と比較すると，台風接近の年 に $15 \mathrm{~m} / \mathrm{s}$ 以上の風が出現しやすい傾向がうかがえる.ま た, 台風が接近しない年でも, 最大で $10 \mathrm{~m} / \mathrm{s}$ 以上の風が 吹いていることがわかる.

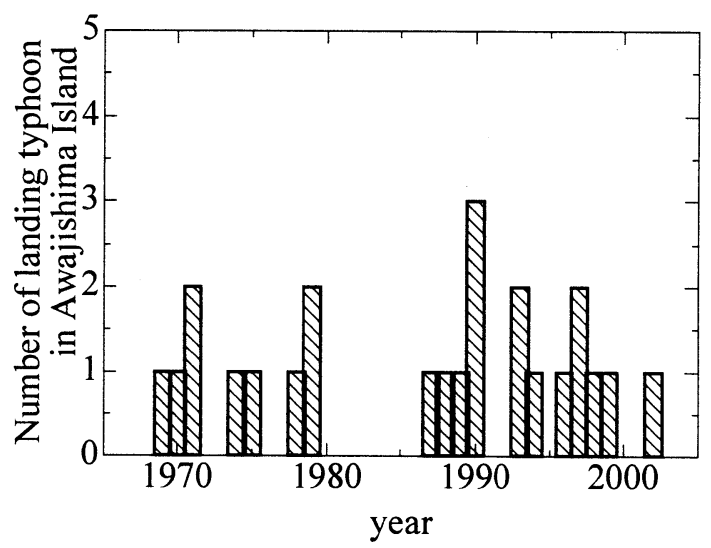

図-8＼cjkstart淡路島に接近・上陸した台風の数（1969年～2003年）

\section{(3) 吹上浜における日飛砂量の推定}

日飛砂量の算定にあたっては，吹上浜付近の平均風速 $3 \mathrm{~m} / \mathrm{s}$ 程度の風速でも移動しうる $\mathrm{d}=0.1 \mathrm{~mm}$ の砂を対象とし た．図-9は月別の平均風速と出現頻度をもとに単位幅あ たりの日飛砂量を南北・東西方向別に算定したものであ る. 春季から夏季にかけては南北方向の飛砂が卓越して いるのに対し，冬季では，南北方向よりも西から東方向 の砂の動きが卓越する結果となっている．ただし，粒径 $0.1 \mathrm{~mm}$ よりさい微細粒子については，粘着力により飛 砂が生じにくくなるとの報告すもある．吹上浜では砂浜 面積や汀線位置が安定していることから，実際にはこう した微細粒子の飛砂による地形変化は起こりにくいので はないかと考えられる。 

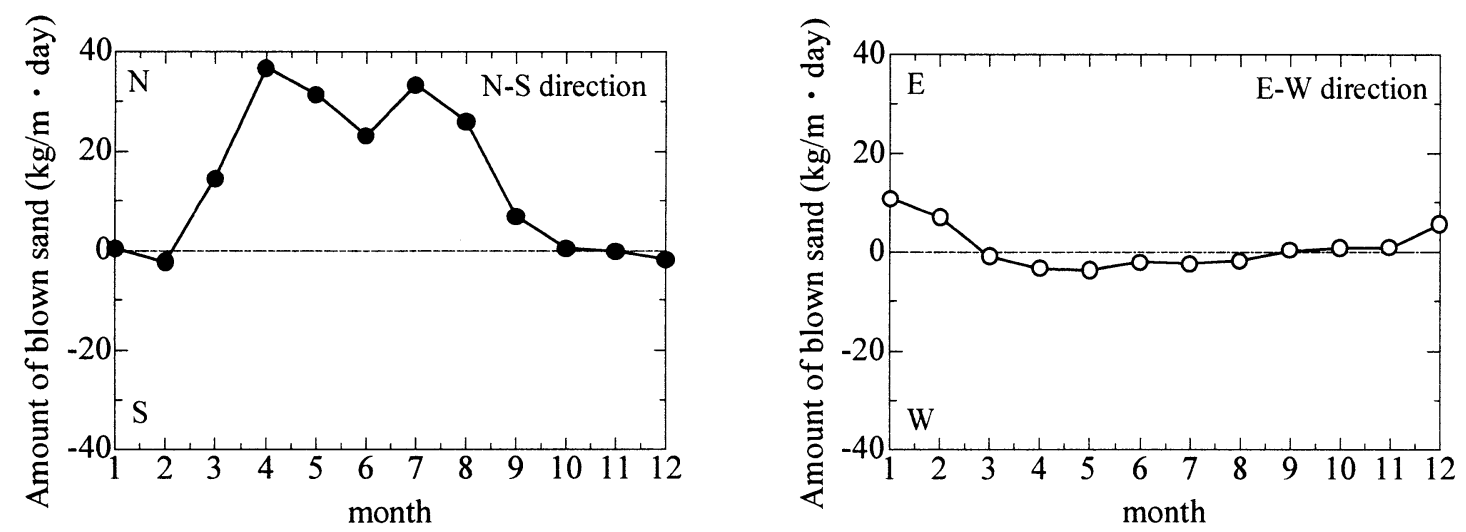

図-9 d=0.1m対象にした日飛砂量の算定結果

\section{4.まとめ}

航空写真ならびに周辺気象データを用いて, 淡路島吹 上浜周辺の砂浜の動態について検討した結果, 以下のこ とが明らかになった。

（1）吹上浜においては，砂浜東端から中央部にかけ ての一時的な汀線後退, 砂浜面積の減少が見られる ものの，1968年から2004年にかけての過去36年の期間 では，概ね安定した砂浜であると判断される.

（2）飛砂や漂砂の重要なファクターになると考えられ る吹上浜周辺の風の特徴についてまとめると, この地 域では年間を通じて $3 \mathrm{~m} / \mathrm{s}$ 程度の風が吹いており, 平均 的な風では粒径0.1mm以下の微細粒子の飛砂しか起こ りえないことがわかった。 また, 吹上浜付近では, 台 風接近や冬季風浪による $15 \sim 20 \mathrm{~m} / \mathrm{s}$ の風の出現が見ら れることから，これらの強風よる飛砂についても検討 する必要がある.

今後は, 出現風向, 風速のより短い時間変化に応じた 飛砂量計算や風波による漂砂について検討を行い, 吹上
浜の砂移動の収支について把握する予定である.

謝辞 : 航空写真は, 兵庫県淡路県民局地域振興部洲本土 地改良事務所ならびに財団法人ひょうご環境創造協会よ り提供を受けました。ここに謝意を表します。

\section{参考文献}

1) 兵庫県 : 淡路沿岸海岸保全基本計画, $6 p, 2002$.

2)気象庁 : 気象統計情報, http//www.jmago.jp/jma/menu/reporthtml

3) Bagnold, R. A. : The Physics of Blown Sand and Desert Dumes, Methuen \& Co. Ltd., 265p., 1954.

4) 河村龍馬 : 飛砂の研究, 東京大学理工学研究所報告, 第 5 巻, 第 3-4 号, pp.95-112, 1951.

5) 河田三治 : 防災林に関する調査報告, 治山事業参考資料, 林 野庁, pp.1-22, 1950.

6) 土屋義人, 河田恵昭 : 飛砂における砂粒の運動機構(1)一砂粒 の移動限界に関する実験一, 京大防災研年報, 第 13 号 $\mathrm{B}$, pp.217-232, 1970.

(2008.3. 10 受付)

(2008.7.3 受理)

Secular cange of the area and the location of shoreline at the Fukiage beach in Awaji island

\title{
Kohji UNO ${ }^{1}$, Shigeki KAKITANI ${ }^{1}$, Gozo TSUJIMOTO $^{1}$, Tetsuya KAKINOKI ${ }^{1}$, Ichiro DEGUCHI ${ }^{2}$ and Mamoru ARITA ${ }^{2}$
}

\author{
${ }^{1}$ Dept. of Civil Engineering, Kobe City College of Technology \\ ${ }^{2}$ Division of Global Architecture, Graduate school of Engineering, Osaka Univ.
}

To clarify the sediment dynamics at the Fukiage Beach which is located in the southwestern part of Awaji island in west Japan, cluster analysis for the aerial photograph were carried out. And the amount of blown sand were estimated using by the monthly prevailing wind direction and the mean wind speed. Main results are as follows; (1) The sediment dynamics at the Fukiage beach has been in equilibrium in past 36 years. (2) The mean wind speed is $2.5-3.0 \mathrm{~m} / \mathrm{s}$ in the vicinity of the Fukiage beach. The wind direction was stood out north and south in winter and summer, respectively. (3) The sediment which diameter is $0.1 \mathrm{~mm}$ or less, can't be transported under the mean wind speed. 